University of Nebraska - Lincoln

DigitalCommons@University of Nebraska - Lincoln

\title{
Variability in Vegetation Effects on Density and Nesting Success of Grassland Birds
}

\author{
Maiken Winter \\ State University of New York \\ Douglas H. Johnson \\ USGS Northern Prairie Wildlife Research Center, Douglas_H_Johnson@usgs.gov \\ Jill A. Shaffer \\ USGS Northern Prairie Wildlife Research Center, jshaffer@usgs.gov
}

Follow this and additional works at: https://digitalcommons.unl.edu/usgsnpwrc

Part of the Other International and Area Studies Commons

Winter, Maiken; Johnson, Douglas H.; and Shaffer, Jill A., "Variability in Vegetation Effects on Density and Nesting Success of Grassland Birds" (2005). USGS Northern Prairie Wildlife Research Center. 233.

https://digitalcommons.unl.edu/usgsnpwrc/233

This Article is brought to you for free and open access by the US Geological Survey at DigitalCommons@University of Nebraska - Lincoln. It has been accepted for inclusion in USGS Northern Prairie Wildlife Research Center by an authorized administrator of DigitalCommons@University of Nebraska - Lincoln. 


\title{
VARIABILITY IN VEGETATION EFFECTS ON DENSITY AND NESTING SUCCESS OF GRASSLAND BIRDS
}

\author{
MAIKEN WINTER, ${ }^{1,2}$ State University of New York, College of Environmental Sciences and Forestry, 1 Forestry Drive, Syracuse, \\ NY 13210, USA \\ DOUGLAS H. JOHNSON, U.S. Geological Survey, Northern Prairie Wildlife Research Center, 8711 37th Street S.E., Jamestown, \\ ND 58401, USA \\ JILL A. SHAFFER, U.S. Geological Survey, Northern Prairie Wildlife Research Center, 8711 37th Street S.E., Jamestown, ND \\ 58401, USA
}

\begin{abstract}
The structure of vegetation in grassland systems, unlike that in forest systems, varies dramatically among years on the same sites, and among regions with similar vegetation. The role of this variation in vegetation structure on bird density and nesting success of grassland birds is poorly understood, primarily because few studies have included sufficiently large temporal and spatial scales to capture the variation in vegetation structure, bird density, or nesting success. To date, no large-scale study on grassland birds has been conducted to investigate whether grassland bird density and nesting success respond similarly to changes in vegetation structure. However, reliable management recommendations require investigations into the distribution and nesting success of grassland birds over larger temporal and spatial scales. In addition, studies need to examine whether bird density and nesting success respond similarly to changing environmental conditions. We investigated the effect of vegetation structure on the density and nesting success of 3 grassland-nesting birds: clay-colored sparrow (Spizella pallida), Savannah sparrow (Passerculus sandwichensis), and bobolink (Dolichonyx oryzivorus) in 3 regions of the northern tallgrass prairie in 1998-2001. Few vegetation features influenced the densities of our study species, and each species responded differently to those vegetation variables. We could identify only 1 variable that clearly influenced nesting success of 1 species: clay-colored sparrow nesting success increased with increasing percentage of nest cover from the surrounding vegetation. Because responses of avian density and nesting success to vegetation measures varied among regions, years, and species, land managers at all times need to provide grasslands with different types of vegetation structure. Management guidelines developed from small-scale, short-term studies may lead to misrepresentations of the needs of grassland-nesting birds.
\end{abstract}

JOURNAL OF WILDLIFE MANAGEMENT 69(1):185-197; 2005

Key words: Bobolink, clay-colored sparrow, density, Dolichonyx oryzivorus, nesting success, Passerculus sandwichensis, Savannah sparrow, Spizella pallida, tallgrass prairie, variability, vegetation structure.

Grasslands are one of the most variable ecosystems in North America, mainly because of unpredictable precipitation patterns among years and regions, and frequent disturbances by fire and grazing. Consequently, local grassland habitat characteristics (such as vegetation height or litter depth) can exhibit large annual variation. Densities of many grassland-nesting birds can be greatly influenced by these local habitat characteristics (reviewed in Johnson and Igl 2001a). Populations of grassland birds thus exhibit large annual and regional fluctuations in population size (Cody 1985, Igl and Johnson 1997) and nesting success (George et al. 1992).

Few studies have extended over a period and over an area large enough to capture the extent of annual and regional variation in grassland bird populations. For shrubsteppe birds in the western United States, Wiens and Rotenberry (1981) showed that bird populations exhibited major

\footnotetext{
${ }^{1}$ Present address: Lab of Ornithology, Cornell University, 159 Sapsucker Woods Road, Ithaca, NY 14850, USA.

2 E-mail: mw267@cornell.edu
}

annual and regional population changes. Recently, Igl and Johnson (1997) reported large annual and regional fluctuations in grassland bird populations in North Dakota. None of these studies directly linked the observed population fluctuations to annual and regional variability in habitat structure. For effective management, however, we need to understand the underlying reasons for the observed population fluctuations.

To date, most studies of annual and regional variation in grassland birds have focused on bird density or abundance (e.g., Johnson and Igl 1997). The few studies that did examine grassland bird nesting success either combined nesting data across years (Patterson and Best 1996, Davis and Sealy 1998) or from several groundnesting species (Koford 1999). Other studies were conducted either over a short period (Kershner and Bollinger 1996, Klute et al. 1997, Hughes et al. 1999) or over a relatively small geographical area (Klute et al. 1997, Winter 1999). The few studies that did report annual variation in grassland bird nesting success did not try to explain the variation by relating nesting success to local 


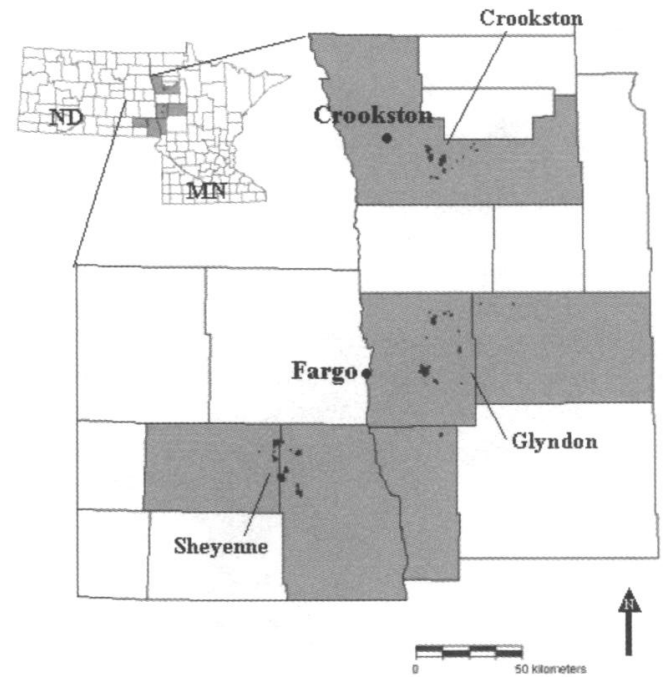

Fig. 1. Study area for determining the effect of vegetation structure on grassland nesting passerines in the northern tallgrass prairie, 1998-2001. Our study was conducted in 3 regions (Crookston, Glyndon, Sheyenne), with each region containing 11-18 study plots. We conducted bird surveys in each study plot; whereas, we conducted nest searching in a subset of the study plots. Cities (Crookston, Fargo) are indicated with a black dot.

habitat features (e.g., McCoy et al. 2001). Given the high variability in vegetation structure and in grassland bird populations, it is imperative that managers understand if and how both density and nesting success vary with vegetation structure among years and regions, and how these responses vary among species. Before applying generalized guidelines for grassland management, assumptions on their effects should therefore be tested among several species, regions, and years.

We investigated density and nesting success of 3 grassland passerines nesting in the northern tallgrass prairie: Clay-colored sparrow, Savannah sparrow, and bobolink. Specifically, we determined: (1) how vegetation structure, bird density, and nesting

Table 1. Number of study sites ( $n$ ), total number of study sites used in all years (site-years), and total size of all study sites combined (based on the number of study sites) used for bird surveys and nest-searching of tallgrass prairie passerines in northwestern Minnesota (Crookston and Glyndon regions, 1998-2001) and southeastern North Dakota (Sheyenne National Grassland, 1999-2001).

\begin{tabular}{lccccccc}
\hline & \multicolumn{3}{c}{ Bird census plots } & & \multicolumn{3}{c}{ Nest search plots $^{\mathrm{a}}$} \\
\cline { 2 - 4 } \cline { 6 - 8 } Region & $n$ & Site-years & Size (ha) & & $n$ & Site-years & Size (ha) \\
\hline Crookston & 15 & 59 & 154 & & $10-12$ & 44 & $104-123$ \\
Glyndon & $18^{\mathrm{b}}$ & 68 & 184 & & $9-11$ & 38 & $91-116$ \\
Sheyenne & 11 & 33 & 129 & & $8-9$ & 26 & $95-111$ \\
\hline
\end{tabular}

a The number of nest search plots varied among years. Therefore, the ranges in $n$ and in the total size of study plots are given.

b $\ln 2001, n=14$ study sites with a total size of 136 ha. success vary among study sites, regions, and years; (2) which vegetation features affect density and nesting success of grassland bird species; (3) whether the effects of vegetation structure on density and nesting success are consistent among years, regions, and species; (4) whether density and nesting success are correlated; and (5) whether climate influences density and nesting success.

\section{STUDY AREA AND METHODS}

We conducted our study in 3 regions in the northern tallgrass prairie: (1) east of Moorhead, Minnesota, in Becker, Mahnomen, and Clay counties (Glyndon); (2) east of Crookston, Minnesota, in Polk County (Crookston); and (3) in southeastern North Dakota at the Sheyenne National Grassland (Sheyenne) in Richland and Ransom counties (Fig. 1). Study sites included tracts owned by the U.S. Fish and Wildlife Service, U.S. Forest Service, Minnesota Department of Natural Resources, and The Nature Conservancy. These tracts were managed by prescribed burning (Crookston and Glyndon) or by rotational grazing (Sheyenne).

We established 44 study plots: 15 in Crookston, 18 in Glyndon, and 11 in Sheyenne (Table 1). Plots were situated in small ( $<50 \mathrm{ha})$ and large (>250 ha) grassland patches and were surrounded by 2 landscape extremes: hostile (e.g., abundant woody vegetation and rowcrop fields) and neutral (e.g., primarily open grassland with as little woody vegetation as possible). The main objective of our study was to determine whether density and nesting success were related to patch size and landscape cover (http://www.npwrc.usgs.gov/resource/2002/bca2001/bca2001.htm). Therefore, we selected study plots to be as similar in vegetation structure and to have as little woody cover as possible to minimize differences in bird assemblages due to vegetation variables. Study plots varied between 1.5 and 20 ha in size $(\bar{x}=10.6$ ha) and were nested within larger tracts of native or restored prairie. Study plots were marked at $50-\mathrm{m}$ intervals along transects that were $100 \mathrm{~m}$ apart. The number of study plots used annually changed slightly among years because of burning or flooding.

Abundance of male breeding birds of all species was determined on each study plot by strip- 
transect censuses. We recorded all birds seen or heard by mapping their location on outlines of each plot. Censuses were conducted between 0500 and $1000 \mathrm{CDT}$, twice each year between late May and early July by MW $(1998,2000)$ and by JAS (1999, 2001). We did not conduct censuses during rain or when wind velocities exceeded 20 $\mathrm{kph}$. The maximum count of the males of a species on a plot was used to determine the species' density (number of males/100 ha).

We measured nesting success on a subset of the study plots (Table 1) by monitoring nest contents roughly every 3 days (range 2-5 days) until the nest terminated. Observers located nests by walking through fields, with or without flushing-sticks, and looking for nests after flushing or observing birds (Winter et al. 2003). We marked nest locations with a small wire flag $5 \mathrm{~m}$ to the north of the nest. A nest was considered successful if it fledged at least 1 young of the parental species. We concentrated nest-searching efforts on the 3 most abundant grassland-nesting passerines in the area: clay-colored sparrow, Savannah sparrow, and bobolink. During the course of the study we found 1,762 nests: 780 clay-colored sparrow, 669 Savannah sparrow, and 313 bobolink.

We evaluated vegetation characteristics in each study plot and at each nest site to determine the associations between bird density or nesting success and habitat characteristics. We measured vegetation structure because previous research has indicated that grassland birds are more influenced by the structure of vegetation than by plant species composition (Wiens 1974). Once in early to mid-July, we quantified plot vegetation at 10 to 32 sampling points per plot (the number of sampling points was dependent on the size of the study plot). We located sampling points at predetermined intervals along plot transects by taking a random number of steps along the transect interval, then taking a random number of steps to the left or right (selected by a coin toss), perpendicular to the transect (Noon 1981). At each sampling point, we measured several vegetation parameters that are outlined below.

We characterized nest vegetation within 1 week after a nest had terminated at sampling points that were located at 5 sites: directly at the nest and at a distance of $0.5 \mathrm{~m}$ from the nest in each cardinal direction (Winter 1999). We also estimated the percentage by which a nest was concealed by vegetation and measured the height of each nest from the ground to the bottom of the nest cup.

At each sampling point for both nest and plot vegetation, we placed a $20 \times 50 \mathrm{~cm}$ Daubenmire
(1959) frame on the ground and measured the percentage of ground cover by growth form (residual vegetation [litter], grass, forb, woody vegetation, and soil). At each corner of the frame, we determined the height of the highest vegetation and litter depth. We defined litter depth as the height at which a meter stick was totally covered by dead plant material that was oriented $0-45^{\circ}$ to the ground. We determined visual obstruction by placing a Robel pole in the middle of each Daubenmire frame and then taking measurements in each of the 4 cardinal directions (Robel et al. 1970). We then calculated the mean of the 4 measurements of litter depth, vegetation height, and visual obstruction at each sampling point. Because vegetation measurements within a study plot or at a nest site are not independent of each other, we pooled data for each study plot or nest site.

We obtained climatic data from 1996-2001 for each region from the National Climatic Data Center (http://lwf.ncdc.noaa.gov/oa/ncdc.html). We obtained monthly precipitation totals from the University of Minnesota's Northwest Experimental Station at Crookston for the Crookston region, from Moorhead for the Glyndon region, and from Lisbon for the Sheyenne region. At Moorhead, precipitation data were missing for 2 months each in 2000 and 2001 . We replaced these missing data by calculating predicted values for the missing months by regressing Moorhead data on Crookston data (PROC GLM). From the precipitation data, we calculated the Conserved Soil Moisture (CSM) Index for each region and year. The Conserved Soil Moisture Index is a weighted average of precipitation during the 21 months preceding May of a particular year. It was developed by Williams and Robertson (1965) for agronomic purposes and popularized for waterfowl biologists by Boyd (1981), who suggested that it mirrored variation in wetlands. Palmer Drought Severity (PDS) Index values for May of each year were obtained for northwestern Minnesota and southeastern North Dakota from the National Climatic Data Center (http://lwf.ncdc.noaa.gov/oa/ncdc.html). The PDS Index incorporates both precipitation and temperature from previous and current years. Both CSM and PDS indices have previously been shown to be useful predictors of bird abundances (Johnson 1996, Igl and Johnson 1999).

\section{Analysis}

Estimation of Variability.-We used the maximum likelihood approach in PROC VARCOMP (SAS 1999) to determine the amount of variability in 
vegetation features and bird density among study plots within regions, among years within regions, and among regions. We then calculated the proportion of variation accounted for by each random effect and by the error estimate.

Avian Density.-Measures of avian density in study plots within 1 geographical region are more likely to be similar than density measures in other regions. Therefore, we used a nested analysis of variance, with the study plot nested within a region. We included year as a repeated effect because bird counts were conducted on the same study plots for several years. Because the models contained both fixed effects (vegetation variables) and random effects (year and plot nested within region), we used PROC MIXED (SAS 1999) to analyze our data (Littell et al. 1996).

We used information-theoretic methods for model selection (Anderson and Burnham 2002, Burnham and Anderson 2002). Because we had numerous potential explanatory variables, as well as their interactions, we first screened for important variables by using cross-validation. For this analysis, we split the data set in half by randomly assigning all data for each study plot to 1 of the 2 halves. In these models, we included as explanatory variables linear and quadratic terms of uncorrelated vegetation variables $(r<0.40)$. Those variables that were statistically significant $(P<0.05)$ in at least 5 out of 20 analyses were kept for consideration in the final analyses. Once we had the list of potentially important variables, we constructed a set of models that included all possible permutations. The final set of models also included those containing geographical region, year, or the interactive effects between (1) geographical region and those vegetation variables that were selected, and (2) geographical region and year. These interactions were included so that we could examine consistency in patterns among regions and years. Analyses were conducted for each species separately.

The relative support from the data for each model was judged using Akaike's Information Criterion (AIC: Lebreton et al. 1992). Because of small sample sizes, we used the criterion adjusted for small sample sizes, $\mathrm{AIC}_{c}$ (Burnham and Anderson 2002). We considered all models with a $\Delta \mathrm{AIC}_{c}<4$ to be plausible, given the data. To determine the reliability of the estimate and the direction of the response, we calculated the model-averaged estimates of regression coefficients and their 90\% confidence intervals (Anderson et al. 2000). Model-averaged standard errors are larger, and confidence intervals wider, than those calculated by standard statistical methods because the model-averaged values acknowledge the uncertainty of the model. In contrast, standard methods assume that the single model selected, of all those examined, is exactly the correct one, which is a very optimistic assumption. We illustrated only those interaction terms that were estimated with relatively high precision, graphing the interactions for which at least 1 confidence interval did not include zero.

Nesting Success.-The fates of nests within a study plot may not be independent because, for example, 1 nest predator can cover an entire plot. In addition, the fates of nests within a region are likely to be more similar to one another than to the fates of nests in another region because of differences in landscape structure among regions that might influence the predator community. We determined how nest vegetation affected nesting success using a double-nested design, with nests nested within study plot, and study plots nested within region. In addition, most nest data were repeatedly collected in the same study plots during 4 different years. To use logistic-type data in a nested analysis with repeated measures, we used GLIMMIX, a SAS Macro for generalized Linear Mixed Models (Wolfinger and O'Connell 1993). We used mixed models because our analyses included both random effects (year and region) and fixed effects (vegetation variables).

Nesting success was calculated using logistic exposure models (Shaffer 2004). This method allows each nest to have unique values of covariates; whereas, nests need to be grouped into specific categories with the Mayfield (1975) method. For this analysis, we split the data into 2 nesting intervals (before and after the penultimate check date), such that the number of observations used in the analysis is higher than the number of nests. As we did with bird density, the vegetation variables entering the final analyses were determined by cross-validation. Relatively few variables had strong predictive relationships with nesting success. Therefore, all variables that had a $P$-value $<$ 0.20 in at least 5 out of 20 analyses were evaluated in the final models. We then used Akaike's Information Criterion to determine the model that was best supported by the data $\left(\Delta \mathrm{AIC}_{c}<4\right)$. Estimates and their confidence limits were backtransformed from the logit scale for presentation (proportion $=e^{\text {estimate }} /\left[1+e^{\text {estimate }}\right]$ ).

A relationship between nesting success and vegetation structure might be spurious because of a 
Table 2. Variability of vegetation structure and bird density among prairies within region (prairie[region]), among years within region (year[region]), and among regions (region) in the northern tallgrass prairie ( $n=160$ for each variable). Bird species include claycolored sparrow (CCSP), Savannah sparrow (SAVS), and bobolink (BOBO). Percentages are derived from the maximum likelihood analysis in PROC VARCOMP (SAS Institute 1999). Data were collected in 3 geographical regions: in northwestern Minnesota (close to Crookston and Glyndon, 1998-2001) and in southeastern North Dakota in Sheyenne National Grassland (1999-2001).

\begin{tabular}{|c|c|c|c|c|c|c|c|c|c|c|c|}
\hline & \multicolumn{5}{|c|}{ Ground cover (\%) } & \multicolumn{6}{|c|}{ Density (males/100 ha) } \\
\hline & Litter & Grass & Forb & Wood & Soil & Deptha & Height $^{b}$ & Robel' & CCSP & SAVS & BOBO \\
\hline Prairie(region) & 18.2 & 46.8 & 50.9 & 56.8 & 13.2 & 15.5 & 29.1 & 33.1 & 62.2 & 61.5 & 47.2 \\
\hline Year(region) & 13.2 & 12.0 & 17.5 & 9.5 & 0.0 & 20.5 & 17.3 & 34.8 & 5.2 & 0.0 & 1.6 \\
\hline Region & 0.0 & 0.0 & 0.0 & 6.5 & 2.8 & 29.3 & 17.4 & 0.0 & 0.0 & 11.9 & 1.5 \\
\hline Error & 68.6 & 41.2 & 31.6 & 27.2 & 84.0 & 34.7 & 36.2 & 32.1 & 32.6 & 26.6 & 49.7 \\
\hline
\end{tabular}

a Depth = mean litter depth $(\mathbf{c m})$.

b Height $=$ mean height of the highest plant $(\mathrm{cm})$.

c Robel $=$ mean value of visual obstruction $(\mathrm{dm})$.

correlation between nesting success and date in the season. To determine which model described nesting success best, we compared the $\mathrm{AIC}_{c}$ values of 3 models: vegetation only (vegetation variable determined by a separate $\mathrm{AIC}_{c}$-based evaluation of vegetation predictors), vegetation and Julian date of last nest check, and interaction between vegetation and Julian date. The model with the lowest $\mathrm{AIC}_{c}$ value (vegetation model) was used in all further analyses.

Once we found the model with the lowest $\mathrm{AIC}_{c}$ value, we determined whether the addition of information on density of the same species improved the support of the data for the model. To do so, we added bird density to the best-supported vegetation model and then compared $\mathrm{AIC}_{c}$ values for the best models on nesting success with and without density, separately for each species.

Climatic Data.-We determined whether climatic data improved the fit of the vegetation model, both for avian density and nesting success, by adding the PDS Index or the CSM Index to the model with the lowest $\mathrm{AIC}_{c}$ value from the previous model sets. If the $\mathrm{AIC}_{c}$ value decreased, then models containing information on climate were deemed better supported by the data.

\section{RESULTS}

Vegetation Characteristics.-Most vegetation measures were by $5-47 \%$ more variable among study plots within a region than among years within a region or among regions (Table 2 ). This pattern suggests that any regional variation was better explained by differences among specific prairies (the Prairie [Region] effect) than by region (the Region effect). The Error estimates, which describe Year (Prairie) effects, are quite large, indicating that most variance in vegetation features $(27-84 \%)$ is the result of year-to-year variation of vegetation parameters within individual prairies. This pattern of variation is inconsistent among prairies.

Litter depth was the only vegetation measure that was more variable among regions (29\%) than among study plots $(15 \%)$ and years $(20 \%)$. The variability of visual obstruction (Robel) was similar among plots (33\%) and among years within a region (35\%). Five vegetation measures (ground cover by litter, grasses, forbs, and woody vegetation; and visual obstruction) were more variable among years within region $(0-17 \%)$ than among regions (0-6\%); whereas, ground cover by bare soil was more variable among regions (3\%) than among years within region (0\%). Variability in vegetation height was similar among years within regions and among regions (17\%).

Although most vegetation features varied more among study sites within a region than among regions, some regional differences were apparent (Table 3). Plots in the Crookston region on average had 6-7\% more ground cover by litter and $5-6 \%$ less ground cover by grass than plots in the other 2 study regions. At Sheyenne, woody cover was about $4 \%$ higher compared to the other 2 regions, forb cover was 4-5\% lower, and vegetation was $11-13 \mathrm{~cm}$ shorter; these variables were similar in the Crookston and Glyndon regions. Litter depth was lowest $(\bar{x}=1.7 \mathrm{~cm})$ at Sheyenne and highest $(\bar{x}$ $=2.9 \mathrm{~cm}$ ) in the Glyndon region; whereas, soil cover was by $3-4 \%$ lower at Glyndon. Visual obstruction was similar among regions $(\bar{x}=22-29 \mathrm{~cm})$.

Avian Density.-Bird density was by $46-57 \%$ more variable among plots within region than among years within region or among regions (Table 2). The low year(region) and region variance does not indicate that bird density did not vary among years and regions. Instead, these results show that density varied among years and regions, but even within a year and region density varied greatly among prairies. The error esti- 
Table 3. Average vegetation structure and bird density (males/100 ha) in study plots of 3 regions in the northern tallgrass prairie, 1998-2001. Avian density was estimated from the maximum count of strip-transect censuses that were conducted twice per year. Plot vegetation was characterized at 10-32 random points within each study plot.

\begin{tabular}{|c|c|c|c|c|c|c|}
\hline \multirow[b]{2}{*}{ Variable } & \multicolumn{2}{|c|}{$\begin{array}{l}\text { Crookston } \\
(n=15)^{a}\end{array}$} & \multicolumn{2}{|c|}{$\begin{array}{l}\text { Glyndon } \\
(n=18)\end{array}$} & \multicolumn{2}{|c|}{$\begin{array}{c}\text { Sheyenne } \\
(n=11)\end{array}$} \\
\hline & $\bar{x}$ & SE & $\bar{x}$ & SE & $\bar{x}$ & SE \\
\hline \multicolumn{7}{|l|}{ Vegetation structure } \\
\hline Litter cover (\%) & 39.0 & 1.7 & 32.7 & 1.5 & 32.2 & 2.0 \\
\hline Grass cover $(\%)$ & 34.6 & 0.7 & 41.0 & 0.8 & 39.7 & 0.9 \\
\hline Forb cover $(\%)$ & 19.2 & 0.9 & 20.7 & 1.3 & 15.6 & 1.5 \\
\hline Woody cover (\%) & 1.6 & 0.3 & 1.8 & 0.3 & 5.4 & 1.3 \\
\hline Soil cover $(\%)$ & 5.2 & 1.2 & 2.2 & 0.7 & 6.0 & 0.8 \\
\hline Litter depth $(\mathrm{cm})$ & 4.0 & 0.3 & 6.1 & 0.3 & 1.7 & 0.2 \\
\hline Vegetation height (cm) & 44.8 & 0.6 & 46.8 & 0.6 & 33.2 & 1.0 \\
\hline Visual obstruction (dm) & 2.4 & 0.1 & 2.9 & 0.1 & 2.2 & 0.2 \\
\hline \multicolumn{7}{|c|}{ Avian density (males/100 ha) } \\
\hline Clay-colored sparrow & 49.1 & 5.8 & 64.2 & 5.8 & 34.8 & 7.7 \\
\hline Savannah sparrow & 125.2 & 8.7 & 76.4 & 7.7 & 59.1 & 10.0 \\
\hline Bobolink & 34.6 & 3.9 & 58.2 & 5.4 & 51.7 & 8.4 \\
\hline
\end{tabular}

${ }^{a} n$ indicates the maximum number of study plots, which differed slightly among years depending on accessibility and burning regime.

mates are quite large (27-50\%), indicating that while about 0.5 to 0.66 of all variance in density was among prairies, there was still 0.33 to 0.5 of all variance in density that was the result of yearto-year variation in density within individual prairies. Regional differences in density measures clearly existed for each species (Table 3 ). Savannah sparrows were the most abundant species in all 3 regions, with average densities ranging between 59-125 males/100 ha. Bobolinks and clay-colored sparrows were most abundant in
Glyndon (58 and 76 males/100 ha, respectively); whereas, Savannah sparrows reached their highest densities in the Crookston region.

Four vegetation variables clearly influenced the density of at least 1 of the 3 study species (Table 4 ). Each species responded differently to these vegetation variables: either different vegetation variables were included in the best-fitting models (Table 4), or species responded in opposite directions to the same variable (Appendix). Each species had at least 1 well-supported model that included region or interactions between region and a vegetation variable (Table 4), indicating that (1) breeding bird density varied among regions, and (2) the response of a species to a variable differed among regions. In addition, models for clay-colored sparrows and boblinks included year, indicating that density of these species varied among years. However, the magnitude of the effect of most predictors within models was not clearly estimated (confidence intervals included zero).

Climatic factors improved the fit of the 


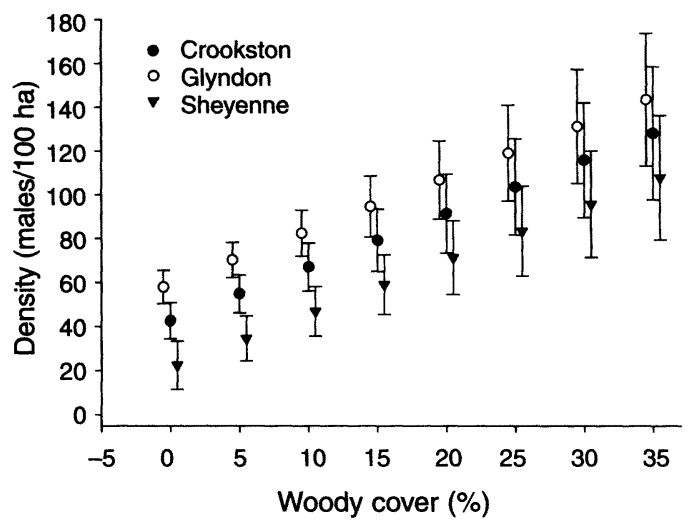

Fig. 2. Estimated values ( \pm standard error) for the effect of woody cover (\%) on clay-colored sparrow density (males/100 ha) in 3 study regions in Minnesota and North Dakota, USA, 1998-2001. Results are based on a PROC MIXED analysis in SAS (1999).

vegetation model for bobolinks; e.g., the model that included the CSM Index was better supported than the vegetation model (vegetation model compared to CSM model: $\Delta \mathrm{AIC}_{c}=2.22$, Akaike weight $=0.23$ ). The fit of the vegetation model of the other 2 species did not improve when climatic variables were added.

Clay-colored sparrow density was described by 10 models, all with $\Delta \mathrm{AIC}_{c}<4$ that incorporated, besides year and region, 3 vegetation variables: ground cover by woody vegetation, litter depth, and the square of vegetation height (Table 4). Clay-colored sparrow density increased with woody cover by 2.2 pairs per 100 ha for each percentage point increase (Fig. 2, Appendix). An interaction beween woody cover and region indicated that this relationship differed slightly among regions. In addition, clay-colored sparrow density tended to increase with greater litter depth at 1.3 pairs per 100 ha per $\mathrm{cm}$ of litter (Appendix). A negative quadratic effect of vegetation height on clay-colored sparrow density showed that density tended to be highest at intermediate vegetation height. However, the magnitude of this squared relationship was not clear (Appendix). Density also tended to vary among regions (Glyndon supported highest densities) and years (highest density occurred in 1999; Appendix).

Savannah sparrow density was described by 2 models (Table 4); region was included in both, and the square of litter depth was included in 1. Savannah sparrow density was highest at Crookston (Appendix, Table 3). The negative quadratic term of litter depth indicated that Savannah sparrow density was highest at intermediate measures of

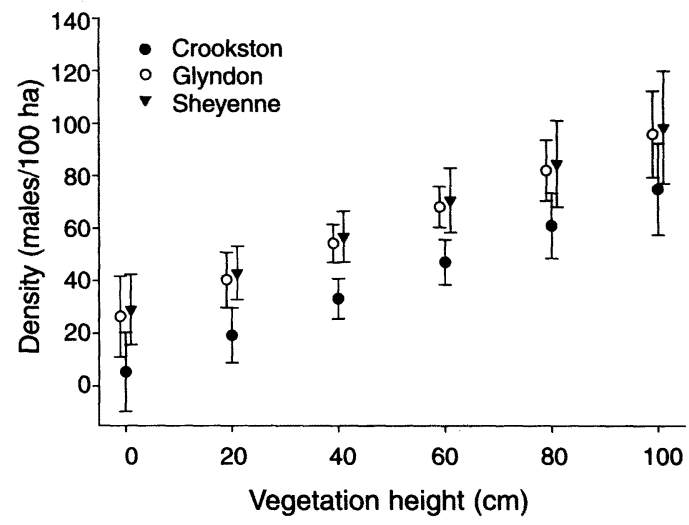

Fig. 3. Estimated values ( \pm standard error) for the effect of vegetation height $(\mathrm{cm})$ on bobolink density (males/100 ha) in 3 study regions in Minnesota and North Dakota, USA, 1998-2001. Results are based on a PROC MIXED analysis in SAS (1999).

litter depth (Appendix). Density did not vary recognizably among years (Tables 2,4 ).

Bobolinks had 3 nearly equally supported models $\left(\Delta \mathrm{AIC}_{c}<4\right)$, including year, grass cover, and an interactive term between region and vegetation height (Table 4). Bobolink density tended to be highest in 1998 (Appendix). In addition, density increased with increasing vegetation height; the magnitude of this increase varied slightly among regions (Fig. 3, Appendix), ranging from 0.43 to 1.23 pairs per 100 ha for each $\mathrm{cm}$ increase in vegetation height.

Nesting Success.-Surprisingly, nesting success did not vary enough among regions or years to be detected statistically. Cross-validation selected 2 vegetation variables (percentage nest cover by vegetation and vegetation height) that were related to nesting success of at least 1 of the 3 study species. However, the only species that was clearly affected by vegetation was the clay-colored sparrow; its nesting success tended to increase with increasing nest cover by the surrounding vegetation (slope $=0.004 \pm 0.003 \%, n=698$ nests, observations used $=1003$ : Fig. $4 a)$. This model had a lower AIC value than the null model (null model compared to vegetation model: $\triangle \mathrm{AIC}_{c}=4.43$, Akaike weight $=0.10$ ).

Savannah sparrow nesting success tended to increase with nest cover (slope $=0.009 \pm 0.004 \%$ ) and with vegetation height (slope $=0.02 \pm 0.01$ $\mathrm{cm}, n=576$ nests, observations used $=757$ ), and bobolink nesting success tended to increase with vegetation height (slope $=0.03 \pm 0.02 \mathrm{~cm}, n=262$ nests, observations used $=360$ ). However, the null model was better supported by the data than the 

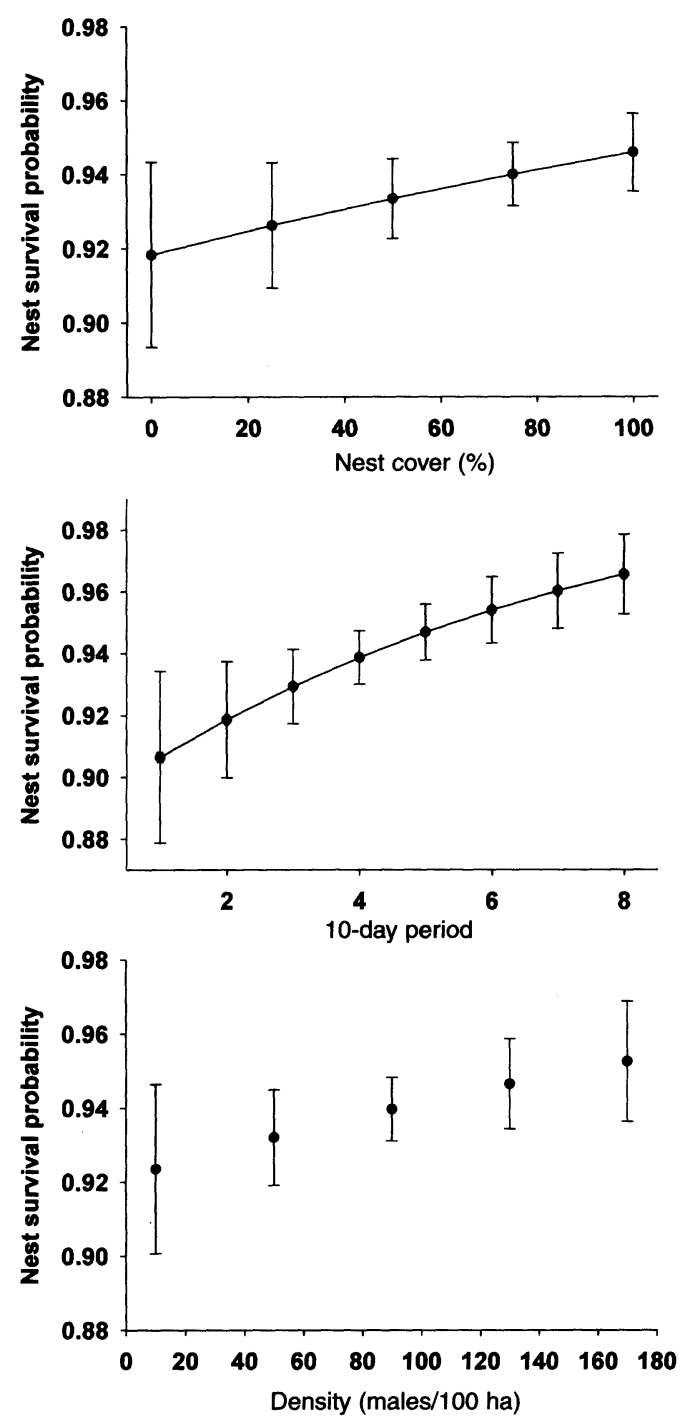

Fig. 4. Estimated values for the relationship between daily nest survival probabilities of clay-colored sparrows and (a) percentage nest cover, (b) week of nest termination during the nesting season (between 21 May and 1 Aug), and (c) clay-colored sparrow density (males/100 ha) in Minnesota and North Dakota tallgrass prairie, 1998-2001. Confidence intervals are asymmetrical around the estimate after back-transformation from the logit scale.

vegetation model for both the Savannah sparrow (Nest cover: $\triangle \mathrm{AIC}_{c}=0.66$, Akaike weight $=0.36$; Vegetation height: $\Delta \mathrm{AIC}_{c}=11.93$, Akaike weight $=0.00$ ), and the bobolink (Vegetation height: $\Delta \mathrm{AIC}_{c}=14.28$, Akaike weight $=0.00$ ).

Vegetation effects on the nesting success of Savannah sparrows and bobolinks were not confounded by the date in the season. In these species, models that included the Julian date of the last nest check (alone or as an interactive term with the vegetation variable) had higher $\Delta \mathrm{AIC}_{c}$ values $(>4)$ than models that did not include the Julian date, indicating that vegetation variables were better predictors of nesting success than Julian date. In clay-colored sparrows, the probability of nesting success increased with the date in the nesting season (slope $=0.01 \pm 0.007 ; n=708$ nests, observations used = 1,014; Fig. 4b). The model that included Julian date as interactive effect had a slightly lower $\mathrm{AIC}_{c}$ value than the model that included only the vegetation variable $\left(\Delta \mathrm{AIC}_{c}=1.3\right)$.

Nesting success was better predicted when we included density information (Table 5) than when vegetation variables alone were used as predictors. For each species, the lowest $\mathrm{AIC}_{c}$ value was for the model that included density: nesting success tended to increase with density of the same species (CCSP: $0.003 \pm 0.003$; Fig. 4c; SAVS: 0.002 \pm 0.002 ; BOBO: $0.0004 \pm 0.005$ ). However, the magnitude of these effects was not clear because confidence intervals for the estimates included zero. The effect of climate was equivocal; models with climatic data were nearly as well supported as models without this information (Table 5).

In summary, models for density and nesting success of the 3 study species included few variables, and these variables differed among species (Table 6). Density did have a slight positive effect on nesting success; whereas, climate did not have a recognizable effect on density or nesting success except for bobolinks, for which climate information improved the models' predicting density.

\section{DISCUSSION}

In our study, local habitat features and bird density varied greatly among plots within a region, among years within region, and among regions. Variation in vegetation structure and bird density among plots within regions was consistently the largest source of variation, although we had selected study plots to be as similar in vegetation structure as possible. Regional differences in vegetation structure were probably partly caused by the grazing regime at Sheyenne, in contrast to the Crookston and Glyndon regions, where study sites were managed by prescribed fire.

We found few vegetation variables that clearly affected the density of our study species (e.g., many confidence intervals included zero). However, model-averaged confidence intervals are wider than those calculated by standard statistical methods because they account for uncertainty about 
what the true model is. The conclusions of our study are therefore less weak than they might appear. The vegetation variables that were included in the best models were consistent with some of those described by other studies (http://www.npwrc.usgs.gov/resource/literatr/ grasbird/bobo/bobo.htm, and http://www. npwrc.usgs.gov/resource/literatr/grasbird/claycolo/claycolo.htm, Swanson 1996). However, in contrast to the findings of many other studies (Wheelwright and Rising 1993, O'Leary and Nyberg 2000, Coppedge et al. 2001), the amount of woody cover within our study plots had no discernible negative effect on Savannah sparrow and bobolink densities. This result may reflect our choice of study sites, favoring sites with little or no woody coverage to represent native tallgrass prairie. The amount of ground cover by woody vegetation within study plots was probably too low $(\bar{x}=$ $2.4 \%$; range: $0-33 \%$ ) to have a negative effect on bird density (Table 3 ).

For each species, models included interactive effects between vegetation variables and region, indicating that the magnitude or even the direction of the response to vegetation structure varied among regions. However, the magnitude of the effect of many variables that we examined was not clear because most estimates were small, with confidence intervals often including zero. Similarly, Fletcher and Koford (2002) reported relatively weak bird-habitat relationships for grassland passerines in northern lowa.

Among species, no vegetation variable affected density in a similar fash- ion; species either differed in the type of vegetation variables that affected their density or in the direction of their response. The response of 1 grassland bird species to vegetation variables, therefore, cannot be extrapolated to that of another species, even if the species are ecologically similar (such as Savannah sparrows and bobolinks). Similarly, Herkert (1994) found that grassland passerines in Illinois varied markedly in the direction of their response to vegetation variables, and Wiens and Rotenberry (1981) reported that shrubsteppe bird populations vary independently of one another. These results indicate

Table 5. The best-fitting models relating nesting success to vegetation structure improve their fit if density of the species in question and climate data are included. Data were collected for 3 grassland passerines in 3 regions of the Minnesota and North Dakota tallgrass prairie, 1998-2001. Clay-colored sparrow (CCSP: $n=698$ nests, observations =1,003): vegetation = nest cover, climate = Palmer Drought Index (PDI). Savannah sparrow (SAVS: $n=576$, observations $=757$ ): vegetation $=$ nest cover, climate $=$ Conserved Soil Moisture Index. Bobolink (BOBO: $n=262$, observations $=360$ ): vegetation $=$ vegetation height, climate $=$ PDI. Nesting success was calculated using logistic exposure models. Effects of all variables were estimable, and al models included 2 random effects (year and plot[region]). The number of estimable parameters $K$ is therefore the number of variables in the model plus 2 .

\begin{tabular}{|c|c|c|c|}
\hline Species & Model parameters & $\Delta \mathrm{AlC}_{c}^{\mathrm{a}}$ & Weight $^{b}$ \\
\hline \multirow[t]{13}{*}{ CCSP } & Vegetation $\times$ Date, Density & 0.00 & 0.32 \\
\hline & Vegetation $\times$ Date, Density $\times$ Climate & 0.23 & 0.28 \\
\hline & Vegetation $\times$ Date, Density, Climate & 1.07 & 0.19 \\
\hline & Vegetation $\times$ Date, Vegetation $\times$ Density & 1.27 & 0.17 \\
\hline & Density $\times$ Climate & 6.26 & 0.01 \\
\hline & Density, Climate & 6.33 & 0.01 \\
\hline & Density & 6.38 & 0.01 \\
\hline & Vegetation $\times$ Date, Climate & 19.78 & 0.00 \\
\hline & Vegetation $\times$ Date, Vegetation $\times$ Density & 19.93 & 0.00 \\
\hline & Climate & 24.40 & 0.00 \\
\hline & Vegetation $\times$ Date & 83.84 & 0.00 \\
\hline & Vegetation & 85.13 & 0.00 \\
\hline & Date & 103.92 & 0.00 \\
\hline \multirow[t]{11}{*}{ SAVS } & Density & 0.00 & 0.26 \\
\hline & Vegetation, Density & 0.46 & 0.21 \\
\hline & Density $\times$ Climate & 0.84 & 0.17 \\
\hline & Density $\times$ Climate, Vegetation & 1.37 & 0.13 \\
\hline & Density, Climate & 2.00 & 0.10 \\
\hline & Vegetation, Climate, Density & 2.42 & 0.08 \\
\hline & Vegetation $\times$ Density & 3.27 & 0.05 \\
\hline & Climate & 23.70 & 0.00 \\
\hline & Vegetation $\times$ Climate & 23.77 & 0.00 \\
\hline & Vegetation, Climate & 24.80 & 0.00 \\
\hline & Vegetation & 123.90 & 0.00 \\
\hline \multirow[t]{11}{*}{$\mathrm{BOBO}$} & Density $\times$ Climate & 0.00 & 0.39 \\
\hline & Density & 0.11 & 0.37 \\
\hline & Vegetation $\times$ Density & 2.26 & 0.13 \\
\hline & Density, Climate & 2.44 & 0.12 \\
\hline & Vegetation, Density & 13.05 & 0.00 \\
\hline & Vegetation, Density $\times$ Climate & 13.26 & 0.00 \\
\hline & Vegetation, Density, Climate & 15.59 & 0.00 \\
\hline & Climate & 22.17 & 0.00 \\
\hline & Vegetation $\times$ Climate & 25.26 & 0.00 \\
\hline & Vegetation, Climate & 35.95 & 0.00 \\
\hline & Vegetation & 70.70 & 0.00 \\
\hline
\end{tabular}

${ }^{a} \triangle \mathrm{AlC}_{c}$ is the difference between the best fitting model and model $\mathrm{i}$.

b Akaike weights indicate the relative importance of 1 model parameter. 
Table 6. The vegetation variables that affect density (males/100 ha; $n=$ number of study plots) and probability of nesting success (Nest; $n=$ number of nests) differ among 3 grassland-nesting species in the northern tallgrass prairie, 1998-2001. Positive linear effects are abbreviated as "+", and negative linear effects as "-." Both positive and negative effects can occur in interactions with region ("+/-). Effects are shown in parentheses when $90 \%$ confidence intervals of the estimates include zero (see Appendix). Effects with a superscript of 2 indicate quadratic effects.

\begin{tabular}{|c|c|c|c|c|c|c|}
\hline \multirow[b]{2}{*}{ Variable } & \multicolumn{2}{|c|}{$\begin{array}{c}\text { Clay-colored } \\
\text { sparrow }\end{array}$} & \multicolumn{2}{|c|}{$\begin{array}{l}\text { Savannah } \\
\text { sparrow }\end{array}$} & \multicolumn{2}{|c|}{ Bobolink } \\
\hline & $\begin{array}{l}\text { Density } \\
(n=160)\end{array}$ & $\begin{array}{c}\text { Nest } \\
(n=696)\end{array}$ & $\begin{array}{l}\text { Density } \\
(n=160)\end{array}$ & $\begin{array}{c}\text { Nest } \\
(n=576)\end{array}$ & $\begin{array}{l}\text { Density } \\
(n=160)\end{array}$ & $\begin{array}{c}\text { Nest } \\
(n=266)\end{array}$ \\
\hline Vegetation height & $(-) 2$ & & & $(+)$ & + & $(+)$ \\
\hline Litter depth & $(+)$ & & $(-) 2$ & & & \\
\hline Woody cover & + & & & & & \\
\hline Grass cover & & & & & $(+)$ & \\
\hline Soil cover & & & & & & \\
\hline Nest cover & N/A & + & N/A & $(+)$ & N/A & \\
\hline Bird density & N/A & $(+)$ & N/A & $(+)$ & N/A & $(+)$ \\
\hline
\end{tabular}

1992a, Dion et al. 2000, Pietz and Granfors 2000).

In clay-colored and Savannah sparrows, the vegetation variables that affected nesting success differed from those influencing bird density. Density responses to vegetation structure therefore do not imply similar effects on nesting success. We only know of 1 other study that investigated the effects of vegetation on both density and nesting success in grassland birds; Hughes

that-especially in highly variable systems such as grasslands-we need to establish long-term and large-scale studies to identify patterns of and understand causes for variability in grassland bird density.

The variation in nesting success among study plots within regions or years was great enough that no overall differences among regions or years were detected. Clay-colored sparrow was the only species for which nesting success was recognizably affected by vegetation structure: nesting success increased with a higher percentage nest cover. The fact that seemingly clear relationships between nesting success and vegetation variables -as we documented for Savannah sparrows and bobolinks-were less well supported by the data than the null models indicates that the potential effect of vegetation was not consistent and strong enough in these species to warrant management recommendation based on these results. In a concurrent study at 1 of our study regions, Sheyenne National Grassland, Scheiman et al. (2003) found a positive influence of grass and forb cover but no influence of vegetation height on Savannah sparrow nesting success; however, sample size was low ( $n=15$ nests), and clay-colored sparrows were not investigated. Few other studies have found vegetation features that influence nesting success in grassland passerines (Winter 1999, Hughes et al. 2000, Moss 2001). Many other studies did not find any effect of vegetation on nesting success in grassland passerines (Vickery et al. 1992a, Koford 1999, Howard et al. 2001). In grasslands, vegetation structure might not be a good predictor of nesting success because of the diverse array of species that depredate grassland birds and their eggs (Vickery et al. et al. (1999) also reported that different vegetation variables affected dickcissel (Spiza americana) density and nesting success.

In our study, nesting success tended to be positively related to bird density, but confidence limits around the estimates were too large to predict this response with confidence. In contrast to our results, Vickery et al. (1992b) reported a negative relationship between density and an index of reproductive success for Savannah sparrows in the northeastern United States. These contradictory findings indicate that even if density predicts nesting success in 1 study, this relationship cannot be extrapolated to other regions.

Climatic factors had no detectable effect on density or nesting success, but this might be the result of little climatic variability because the duration of the study was too short (4 years), and because the 3 regions of the study were too close to each other (see Fig. 1). Igl and Johnson (1999), who found that climatic variables had large effects on Le Conte's sparrow density, used a much larger data set (nearly 300 fields) that covered 7 years (including drought and deluge) and 4 states (Minnesota, Montana, North Dakota, South Dakota). In addition, Igl and Johnson's (1999) data suggest that a species' response to climate might be delayed by 1 or 2 years. Such a time lag would make it difficult for short-term studies to detect any climatic effects.

\section{MANAGEMENT IMPLICATIONS}

The high annual and regional variability in grassland systems requires that studies on grassland-nesting birds extend over a wide geographical region and over several years (Igl and John- 
son 1999). Studies on relatively stable featuressuch as patch size and landscape patterns-will not be able to explain this variability and thus will not improve our understanding of the features that cause the variability in grassland birds. In our study, grassland bird density and nesting success were affected by different vegetation variables, and those variables differed among bird species. Therefore, we cannot suggest any vegetation variable that would render easy management recommendations to simultaneously maximize density and nesting success of the 3 study species. Similarly, Walk and Warner (2000) reported that habitats with different management regimes were preferred by different grassland bird species, and Swengel and Swengel (2001) indicated that 3 grassland bird species in Missouri preferred different amounts of litter. Management for several grassland species thus requires the establishment of a mosaic management regime, which provides optimal habitat for several species simultaneously (Herkert et al. 1996, Dale et al. 1997, Madden et al. 2000, McMaster and Davis 2001).

The lack of recognizable effects of vegetation structure on nesting success in 2 of the 3 study species might make it impossible to develop specific management recommendations to increase nesting success in our study system. Even though density did not clearly predict nesting success, it tended to be positively related to nesting success. We might have to rely on density data to be able to give any reasonable management guidelines. Analyses on the effect of patch size and landscape structure on density and nesting success (Winter et al. in press) may provide more insights into determinants of habitat quality in the northern tallgrass prairie.

\section{ACKNOWLEDGMENTS}

We are highly indebted to T. L. Shaffer, who developed the methodology for our analyses on nesting success. Thanks to W. D. Svedarsky and T. M. Donovan for their cooperation during the entire project and to B. R. Euliss for helping in numerous ways. W. M. Hochachka, L. D. Igl, R. R. Koford, S. Swengel, and D. A. Wolfe provided valuable comments and other assistance with earlier drafts of the manuscript. Thanks to all field assistants who spent many early hours covered by mosquitoes while trying to find the well-hidden nests of our elusive study species. This study was funded by the U.S. Geological Survey and by the U.S. Fish and Wildlife Service, Regions 3 and 6.

\section{LITERATURE CITED}

ANDERSON, D. R., AND K. P. Burnham. 2002. Avoiding pitfalls when using information-theoretic methods. Journal of Wildlife Management 66:912-918.

$\longrightarrow,-$, AND W. L. THOMPSON. 2000. Null hypothesis testing: problems, prevalence, and an alternative. Journal of Wildlife Management 64:912-923.

BoYD, H. 1981. Prairie dabbling ducks, 1941-1980. Canadian Wildlife Service Progress Notes 119.

BURNHAM, K. P., AND D. R. ANDERSON. 2002. Model selection and inference: a practical information-theoretic approach. Second edition, Springer Verlag, New York, USA.

CoDY, M. L. 1985. Habitat selection in grassland and open-country birds. Pages 191-226 in M. L. Cody, editor. Habitat selection in birds. Academic Press, Orlando, Florida, USA.

Coppedge, B. R., D. M. Engle, R. E. Masters, AND M. S. GREGORY. 2001. Avian response to landscape change in fragmented southern Great Plains grasslands. Ecological Applications 11:47-59.

DAle, B. C., P. A. MARTin, AND P. S. TAYlor. 1997. Effects of hay management on grassland songbirds in Saskatchewan. Wildlife Society Bulletin 25:616-626.

DAUBENMIRE, R. 1959. A canopy-coverage method of vegetational analysis. Northwest Scientist 33:43-64.

Davis, S. K., AND S. G. SEALY. 1998. Nesting biology of the Baird's sparrow in southwestern Manitoba. Wilson Bulletin 110:262-270.

DION, N., K. A. HOBSON, AND S. LARIVIERE. 2000. Interactive effects of vegetation and predators on the success of natural and simulated nests of grassland songbirds. Condor 102:629-634.

FLETCHER, R. J., AND R. R. KOFORD. 2002. Habitat and landscape associations of breeding birds in native and restored grasslands. Journal of Wildlife Management 66:1011-1022.

GeORGE, T. L., A. C. Fowler, R. L. KNIGHT, AND L. C. MCEWEN. 1992. Impacts of a severe drought on grassland birds in western North Dakota. Ecological Applications 2:275-284.

HERKERT, J. R. 1994. The effect of habitat fragmentation on midwestern grassland bird communities. Ecological Applications 4:461-471.

-, D. W SAMPLE, AND R. E. WARNER. 1996. Management of midwestern grassland landscapes for the conservation of migratory birds. Pages 89-116 in F. R. Thompson III, editor. Managing midwestern landscapes for the conservation of Neotropical migratory birds. U.S. Forest Service, General Technical Report NC-187.

Howard, M. N., S. K. SKagen, AND P. L. KENNEDY. 2001. Does habitat fragmentation influence nest predation in the shortgrass prairie? Condor 103:530-536.

Hughes, J. P., R. J. RoBEL, AND K. E. KEMP. 2000. Factors influencing mourning dove nesting success in CRP fields. Journal of Wildlife Management 64:1004-1008. -, AND J. L. ZimMERMAN. 1999. Effects of habitat on dickcissel abundance and nesting success in Conservation Reserve Program fields in Kansas. Journal of Wildlife Management 63:523-529.

IGL, L. D., AND D. H. JoHNSON. 1997. Changes in breeding bird populations in North Dakota: 1967 to 1992-93. Auk 114:74-92.

$\longrightarrow$, AND $\longrightarrow$ 1999. Le Conte's sparrows breeding in Conservation Reserve Program fields: precipi- 
tation and patterns of population change. Pages 178-186 in P. D. Vickery and J. R. Herkert, editors. Ecology and conservation of grassland birds of the western hemisphere. Studies in Avian Biology 19.

JoHnSON, D. H. 1996. Waterfowl communities in the northern plains. Pages 391-418 in M. L. Cody and J. A. Smallwood, editors. Long term studies of vertebrate communities. Academic Press, San Diego, California, USA.

- AND L. D. IGL, series coordinators. $2001 a$. Effects of management practices on grassland birds. Northern Prairie Wildlife Research Center, Jamestown, North Dakota. http://www.npwrc.usgs.gov/ resource/literatr/grasbird/grasbird.htm.

, AND - $2001 b$. Area requirements of grassland birds: a regional perspective. Auk 118:24-34.

KerSHNER, E. L., AND E. K. BOLLINGER. 1996. Reproductive success of grassland birds at east-central Illinois airports. American Midland Naturalist 136:358-366.

KLUTE, D. S., R. J. RoBEL, AND K. E. KEMP. 1997. Will conversion of Conservation Reserve Program (CRP) lands to pasture be detrimental for grassland birds in Kansas? American Midland Naturalist 137:206-212.

KOFORD, R. R. 1999. Density and fledging success of grassland birds in Conservation Reserve Program fields in North Dakota and west-central Minnesota. Pages 187-195 in P. D. Vickery and J. R. Herkert, editors. Ecology and conservation of grassland birds of the western hemisphere. Studies in Avian Biology 19.

Lebreton, J. D., K. P. Burnham, J. Clobert, AND D. R. ANDERSON. 1992. Modeling survival and testing biological hypotheses using marked animals: a unified approach with case studies. Ecological Monographs 62:67-118.

LitTELl, R. C., R. K. MURPHY, A. J. HANSEN, AND L. MURRAY. 2000. Models for guiding management of prairie bird habitat in northwestern North Dakota. American Midland Naturalist 144:377-392.

- P. R. HeNRY, AND C. B. AMmerman. 1996. Mixed model SAS procedures with emphasis on repeated measures. Journal of Animal Science 74:274.

MAurer, B. A. 1986. Predicting habitat quality for grassland birds using density-habitat correlations. Journal of Wildlife Management 50:556-566.

Madden, E. M., R. K. MurPhy, A. J. HANSEN, AND L. MuRRAY. 2000. Models for guiding management for prairie bird habitat in northwestern North Dakota. American Midland Naturalist 144:377-392.

MAYFIELD, H. F. 1975. Suggestions for calculating nesting success. Wilson Bulletin 87:456-466.

MCCOY, T. D., R. M. RYAN, AND L. W. BURger. 2001. Grassland bird conservation: CP1 vs. CP2 plantings in Conservation Reserve Program fields in Missouri. American Midland Naturalist 145:1-17.

MCMASTER, D. G., AND S. K. DAVIS. 2001. An evaluation of Canada's Permanent Cover Program: habitat for grassland birds? Journal of Field Ornithology 72:195-210.

Moss, E. D. 2001. Distribution and reproductive success of native grassland birds in response to burning and field size at Fort Campbell Military Reservation: special focus on Henslow's and grasshopper sparrows. Thesis, University of Tennessee, Knoxville, USA.

Noon, B. R. 1981. Techniques for sampling avian habitats. Pages 42-52 in D. E. Capen, editor. The use of multivariate statistics in studies of wildlife habitat. U.S. Forest Service General Technical Report RM-87.

O'Leary, C. H., AND D. W. NyBERG. 2000. Treelines between fields reduce the density of grassland birds. Natural Areas Journal 20:243-249.

PAtTerson, M. P., AND L. B. BEST. 1996. Bird abundance and nesting in Iowa CRP fields: the importance of vegetation structure and composition. American Midland Naturalist 135:153-167.

PIETZ, P. J., AND D. A. GRANFORS. 2000. Identifying predators and fates of grassland passerine nests using miniature video cameras. Journal of Wildlife Management 64:71-87.

RIBIC, C. A., AND D. W. SAMPLE. 2001. Associations of grassland birds with landscape factors in southern Wisconsin. American Midland Naturalist 146:105-121.

Risser, P. G., E. C. BiRney, H. D. Blocker, S. W. May, W. J. PARTON, AND J. A. WiENS. 1981. The true prairie ecosystem. Hutchinson Ross Publishing, Stroudsburg, Pennsylvania, USA.

Robel, R. J., J. N. Briggs, A. D. Dayton, AND L. C. HulBERT. 1970. Relationship between visual obstruction measurements and weight of grassland vegetation. Journal of Range Management 23:295-297.

SAS INSTITUTE. 1999. The SAS system for Windows, version 8.0. SAS Institute, Cary, North Carolina, USA.

SCHEIMAN, D. M., E. K. Bollinger, AND D. H. JoHNSON. 2003. Effects of leafy spurge infestation on grassland birds. Journal of Wildlife Management 67:115-121.

ShAFFER, T. L. 2004. A unified approach to analyzing nest success. Auk 121:526-540.

SWANSON, D. A. 1996. Nesting ecology and nesting habitat requirements of Ohio's grassland-nesting birds: a literature review. Ohio Fish and Wildlife Report 13. Ohio Department of Natural Resources, Division of Wildlife, Columbus, USA.

SwENGEL, S. R., AND A. B. SwENGEL. 2001. Relative effects of litter and management on grassland bird abundance in Missouri, USA. Bird Conservation International 11:113-128.

Thompson, F. R., J. D. Brawn, S. Robinson, J. FAaborg, AND R. L. CLAWSON. 2000. Approaches to investigate effects of forest management on birds in eastern deciduous forests: how reliable is our knowledge? Wildlife Society Bulletin 28:1111-1122.

VICKERY, P. D., M. L. HUNTER, AND J. V. WELls. 1992a. Evidence of incidental nest predation and its effects on nests of threatened grassland birds. Oikos 63:281-288. ,$- \ldots$, AND $-1992 b$. Is density an indicator of breeding success? Auk 109:706-710.

WALK, J. W., AND R. E. WARNER. 2000. Grassland management for the conservation of songbirds in the midwestern USA. Biological Conservation 94:165-172.

WheElWRight, N. T., AND J. D. Rising. 1993. Savannah sparrow (Passerculus sandwichensis). Number 45 in A. Poole and F. Gill, editors. The birds of North America. The Academy of Natural Sciences, Philadelphia, Pennsylvania, USA, and The American Ornithologist's Union, Washington, D.C., USA.

WIENS, J. A. 1974. Climatic instability and the "ecological saturation" of bird communities in North American grasslands. Condor 76:385-400.

- AND J. T. ROTENBERRY. 1981. Habitat associations and community structure of birds in shrubsteppe environments. Ecological Monographs 51:21-41.

WILlIAMS, G. D., AND G. W. ROBERTSON. 1965. Estimating most probable prairie wheat production from precipitation data. Canadian Journal of Plant Science 45:34-47. 
WINTER, M. 1999. Nesting biology of dickcissels and Henslow's sparrows in southwestern Missouri prairie fragments. Wilson Bulletin 111:515-527.

- S. Hawks, J. A. ShafFER, AND D. H. JohnSON. 2003. Guidelines for finding nests of passerine birds in tallgrass prairie. Prairie Naturalist 35:197-211.

-, D. H. Johnson, J. A. Shaffer, T. M. Donovan, AND W. D. SvedARSKY. 2005. Patch size and landscape effects on density and nesting success of grassland birds. Journal of Wildlife Management 69:in press.

WOLFINGER, R., AND M. O'CONNELL. 1993. Generalized linear mixed models: a pseudo-likelihood approach. Journal of Statistical Computation and Simulation 48:233-243.

Associate Editor: Boal.

Appendix. Model-averaged results (with lower and upper $90 \%$ confidence intervals) of models on the effect of vegetation variables on density of clay-colored sparrows (CCSP), Savannah sparrows (SAVS), and bobolinks (BOBO) in the northern tallgrass prairie, 1998-2001. Models were averaged from all models that had a $\triangle A I C_{c}$ value $<4$.

\begin{tabular}{|c|c|c|c|c|c|c|}
\hline Species & Parameter & Year & Region & Estimate & $\mathrm{LCl}$ & $\mathrm{UCI}$ \\
\hline \multirow[t]{22}{*}{$\operatorname{CCSP}$} & Intercept & & & 25.84 & 2.33 & 49.34 \\
\hline & Woody cover & & & 2.20 & 0.60 & 3.81 \\
\hline & Litter depth & & & 1.26 & -1.10 & 3.62 \\
\hline & ${\text { (Vegetation height })^{2}}^{2}$ & & & -0.01 & -0.01 & 0.00 \\
\hline & Region & & Crookston & 19.22 & -8.84 & 47.28 \\
\hline & & & Glyndon & 29.84 & -6.83 & 66.50 \\
\hline & Year & 1998 & & -0.84 & -12.87 & 11.19 \\
\hline & & 1999 & & 12.47 & -3.21 & 28.15 \\
\hline & & 2000 & & -1.19 & -9.32 & 6.94 \\
\hline & Woody cover $\times$ Region & & Crookston & -0.06 & -0.35 & 0.22 \\
\hline & & & Glyndon & 0.00 & -0.28 & 0.47 \\
\hline & & & Sheyenne & 0.20 & -0.44 & 0.83 \\
\hline & Year $\times$ Region & 1998 & Crookston & 3.14 & -7.10 & 13.38 \\
\hline & & & Glyndon & 6.04 & -12.11 & 24.20 \\
\hline & & 1999 & Crookston & 6.76 & -13.41 & 26.93 \\
\hline & & & Glyndon & 7.01 & -13.85 & 27.88 \\
\hline & & & Sheyenne & 0.29 & -2.80 & 3.38 \\
\hline & & 2000 & Crookston & 3.24 & -7.23 & 13.70 \\
\hline & & & Glyndon & 4.77 & -9.78 & 19.32 \\
\hline & & & Sheyenne & 0.30 & -2.41 & 3.01 \\
\hline & & 2001 & Crookston & 3.38 & -7.43 & 14.19 \\
\hline & & & Glyndon & 4.69 & -9.67 & 19.06 \\
\hline \multirow[t]{4}{*}{ SAVS } & Intercept & & & 59.53 & 29.49 & 89.58 \\
\hline & Region & & Crookston & 74.17 & 35.04 & 113.30 \\
\hline & & & Glyndon & 26.62 & -12.31 & 65.54 \\
\hline & (Litter depth) $)^{2}$ & & & -0.26 & -0.52 & 0.00 \\
\hline \multirow[t]{7}{*}{ ВОВО } & Grass cover & & & 0.15 & -0.26 & 0.56 \\
\hline & Vegetation height $\times$ Region & & Crookston & 0.43 & -0.08 & 0.95 \\
\hline & & & Glyndon & 0.76 & 0.28 & 1.24 \\
\hline & & & Sheyenne & 1.23 & 0.55 & 1.90 \\
\hline & Year & 1998 & & 0.21 & -2.39 & 2.80 \\
\hline & & 1999 & & -0.15 & -2.22 & 1.92 \\
\hline & & 2000 & & -1.46 & -6.02 & 3.11 \\
\hline
\end{tabular}

